\title{
THE EXTRACELLULAR MATRIX OF REPARATIVE TISSUE IN THE VITREOUS: FIBRONECTIN PRODUCTION IN PROLIFERATIVE DIABETIC RETINOPATHY MEMBRANES
}

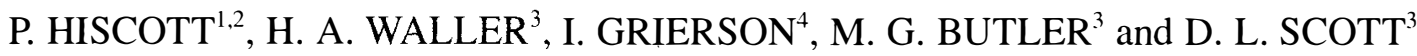 \\ London and Liverpool
}

\begin{abstract}
SUMMARY
In a preliminary investigation into the origins of the extracellular matrix glycoprotein fibronectin in proliferative diabetic retinopathy (PDR) membranes, four globes containing PDR membranes were subjected to in situ hybridisation and immunohistochemical studies. Fibronectin mRNA was found in PDR membrane cells in two of the four globes. The fibronectin-producing cells exhibited fibroblast-like or macrophage-like morphology. Occasional intraretinal macrophage-like cells which contained fibronectin mRNA were also observed in three of the eyes. Variable fibronectin immunoreactivity was observed in all the PDR membranes, while the fibronectin staining pattern in the underlying retina was similar to that reported for albumin in eyes with breakdown of the blood-retina barrier. The findings suggest that fibronectin in PDR membranes originates from both plasma-derived fibronectin and the membrane cells, and support the concept that extracellular matrix components play an important role in PDR membrane progression.
\end{abstract}

Fibrosis may occur at several sites in the vitreous cavity; most commonly it is encountered at the vitreoretinal interface where it gives rise to membranes on the retinal surface (epiretinal membranes) and in the vitreous cortex (posterior hyaloid membranes) (reviewed by Reeser and Aaberg ${ }^{1}$ and $\left.\mathrm{McLeod}^{2}\right)$. The membranes at the vitreoretinal juncture are seen as complications of various pathological events such as retinal detachment and proliferative diabetic retinopathy (PDR). In contrast to the

From: 'Departments of Pathology and Clinical Science, Institute of Ophthalmology, and ${ }^{2}$ Vitreoretinal Unit, Moortields Eye Hospital, London; ' ${ }^{3}$ Departments of Immunology and Rheumatology, St. Bartholomew's Hospital, London; ${ }^{4}$ Ophthalmic Research Unit, Department of Medicine, Royal Liverpool University Hospital.

Correspondence to: Dr. P. Hiscott, Unit of Ophthalmology, Department of Medicine, University of Liverpool, PO Box 147 , Liverpool L69 3BX, UK. membranes which arise after rhegmatogenous retinal detachment, PDR membranes (including those which follow diabetic vitrectomy such as in retrosilicone oil neovascularisation $^{3.4}$ and some cases of reparative epiretinal fibrosis $^{5}$ ) have a prominent vascular component. ${ }^{2}$

The blood vessels which extend into the vitreoretinal interface during the formation of PDR membranes are accompanied by a variety of cell types including fibroblasts of unknown origin, inflammatory cells, retinal glia and, possibly, retinal pigment epithelial cells. ${ }^{6-13}$ These cells are responsible for several features of PDR membranes such as scar-like contraction ${ }^{14}$ and collagen accumulation in the extracellular matrix (ECM).

\section{The Extracellular Matrix of PDR Membranes}

The collagen of PDR membranes has been investigated by immunofluorescence and SDS polyacrylamide gel electrophoresis and has been shown to contain types I to V. ${ }^{12.15}$ The accretion of collagen in the tissue led to the concept that the cell-mediated contraction within the tissue was consolidated and stabilised by the ECM. ${ }^{2}$ However, the ECM of the membranes has been shown to contain other components such as the ECM glycoproteins. ${ }^{12.15}$ ECM glycoproteins have multiple biological functions encompassing roles in early ECM assembly and in cellsubstratum adhesion. ${ }^{16-18}$ Cell-ECM adhesion is mediated by cell surface receptors including those of the integrin family and it is thought that ECM glycoprotein-integrin interactions profoundly influence cell activities such as cellular proliferation, migration and differentiation. ${ }^{19-21} \mathrm{In}$ view of the effects of ECM glycoproteins on cell behaviour, it is likely that the ECM of PDR membranes not only stabilises membrane contraction but also modulates membrane development. Consequently, much interest has been generated in PDR membrane glycoproteins.

One of the first ECM glycoproteins to be discovered in PDR membranes was fibronectin. ${ }^{12}$ Fibronectin is abun- 
dant in the tissue but its origin in PDR membranes is unclear. There is some evidence that a soluble type of fibronectin (plasma fibronectin) enters the vitreal cavity following breakdown of the blood-retina barrier ${ }^{22.23}$ and could thus become incorporated in developing PDR membranes. However, a form of insoluble fibronectin produced by cells (cellular fibronectin) is also found in PDR membranes $^{24-26}$ and recently we have presented evidence that glial, fibroblastic and retinal pigment epithelial cells can produce fibronectin within some intravitreal membranes. ${ }^{27}$ For example, intravitreal membranes which complicate rhegmatogenous retinal detachment contain cells replete with fibronectin messenger RNA (mRNA) while cells in the underlying retina express little fibronectin mRNA. ${ }^{27}$

To investigate further the origins of fibronectin in PDR membranes we are employing an in situ hybridisation technique to evaluate fibronectin mRNA in cells in membrane specimens and the underlying retina. ${ }^{27}$ The findings are compared with fibronectin immunoreactivity in the specimens. Here we present our preliminary results based on PDR membranes and retina in enucleated eyes.

\section{MATERIALS AND METHODS}

\section{Control Tissue}

Proliferative tissue from rheumatoid arthritis synovium known to contain abundant human cellular fibronectin mRNA and to show strong fibronectin immunoreactivity ${ }^{28}$ was used as the positive control tissue for the hybridisation experiments and immunohistochemical procedures.

\section{Globes Containing PDR Membranes}

Four globes known to contain PDR membranes (Table I) were used in this initial study. The globes were obtained from the files of the Pathology Department at the Institute of Ophthalmology.

\section{Preparation of Single Stranded RNA Probes}

Single stranded RNA probes (riboprobes) were prepared as previously reported..$^{27.28} \mathrm{~A}$ cDNA clone ( $\mathrm{pFH} 1$ ), equivalent to about one quarter of the estimated size of human cellular fibronectin mRNA, ${ }^{29,30}$ was provided by Dr. F. E. Baralle, Sir William Dunn School of Pathology, University of Oxford. The plasmid was double digested, purified and inserted into the SP6/T7 vector Riboprobe Gemini pGEM-blue (pGEM, Promega, Wisconsin, USA).

Radiolabelled anti-sense and sense (control) riboprobes were produced from linearised plasmid template by incorporating ${ }^{35}$ S-labelled CTP (specific activity approx. 800 $\mathrm{Ci} / \mathrm{mmol}$; Amersham International, Bucks., UK) with the standard transcription reaction, employing SP6 or T7 RNA polymerase (Boehringer Mannheim, FRG).

Optimal probe length for tissue penetration was achieved using alkaline hydrolysis and checked by gel electrophoresis and autoradiographic blotting. ${ }^{31}$ Radiolabelled probes were stored at $-20^{\circ} \mathrm{C}$ until used.

\section{Hybridisation Histochemistry}

The globes were fixed for between 4 and 48 hours in 10\% formol-saline, dehydrated in graded concentrations of ethanol and embedded in paraffin wax. Sections ( $6 \mu \mathrm{m}$ thick) of wax-embedded tissue were placed on $2 \% 3$-aminopropyltriethoxysilane-coated glass slides (Sigma, Poole, Dorset, UK), dewaxed and permeabilised. The specimens were treated with Proteinase K, post-fixed, dehydrated and air-dried. The anti-sense (SP6, fibronectin mRNA) probe was then applied at a concentration of $0.2 \mathrm{ng} / \mu \mathrm{l}$ in hybridisation medium. The sections were covered with coverslips overnight at $37^{\circ} \mathrm{C}$ in a humid chamber. To prevent RNAse contamination, RNAse-free conditions were implemented in all methods up to and including hybridisation. Following removal of the coverslips and unbound probe as previously described, ${ }^{27}$ the specimens were dehydrated in ascending concentrations of ethanol containing $0.3 \mathrm{M}$ ammonium acetate and air-dried.

Sites of probe binding were detected autoradiographically. The slides were coated with $\mathrm{K} 5$ nuclear emulsion (Ilford, Cheshire, UK), dried and kept at $4^{\circ} \mathrm{C}$ in the dark. They were then developed with D-19 developer (Kodak, Herts., UK) fixed with Hypam fix, counterstained with Mayer's haematoxylin and mounted.

\section{Control Procedures}

Controls were run to check the specificity of the probe binding: (1) sections were treated with $20 \mu \mathrm{g} / \mathrm{ml}$ RNAse to remove all tissue RNA before hybridisation with the antisense probe; (2) other sections were incubated with the sense (T7) probe at a concentration of $0.2 \mathrm{ng} / \mu \mathrm{l}$ instead of the fibronectin (anti-sense) probe.

\section{Immunohistochemistry}

Serial sections. $6 \mu \mathrm{m}$ thick of the wax-embedded tissue

Table I. Fibronectin mRNA in the cells of intravitreal fibrovascular membranes in enucleated eyes of diabetic patients

\begin{tabular}{|c|c|c|c|c|c|c|c|}
\hline \multirow{2}{*}{$\begin{array}{l}\text { Globe } \\
\text { no. }\end{array}$} & \multicolumn{3}{|c|}{ Patient } & \multirow[b]{2}{*}{ Reason for enucleation } & \multirow[b]{2}{*}{ Location of membrane } & \multirow{2}{*}{$\begin{array}{c}\text { Proportion of } \\
\text { membrane cells } \\
\text { showing moderate } \\
\text { labelling for } \\
\text { fibronectin mRNA (\%) }\end{array}$} & \multirow{2}{*}{$\begin{array}{c}\text { Proportion of } \\
\text { membrane cells } \\
\text { showing intense } \\
\text { labelling for } \\
\text { fibronectin mRNA }(\%)\end{array}$} \\
\hline & Age $(y r)$ & Sex & Eye & & & & \\
\hline 1 & 71 & $\mathrm{~F}$ & $\mathrm{R}$ & Corneal abscess & Epiretinal/posterior hyaloid & $40^{\mathrm{a}}$ & 20 \\
\hline 2 & 64 & $\mathrm{~F}$ & $\mathrm{~L}$ & Thrombotic glaucoma & Epiretinal & $0^{\mathrm{a}}$ & 0 \\
\hline 3 & 69 & $\mathrm{~F}$ & $\mathrm{~L}$ & Thrombotic glaucoma & Epiretinal/posterior hyaloid & $30^{\mathrm{a}}$ & 0 \\
\hline 4 & 65 & $\mathrm{M}$ & $\mathrm{R}$ & Thrombotic glaucoma & Epiretinal/posterior hyaloid. & 0 & 0 \\
\hline
\end{tabular}

F, female; M, male; $R$, right; L, left.

${ }^{a}$ Isolated macrophage-like cells in underlying retina also contained fibronectin mRNA. 
blocks used for in situ hybridisation were immunostained for fibronectin, glial fibrillary acidic protein (GFAP; to detect glial cells) or cytokeratins (to identify retinal pigment epithelial cells) as previously described. ${ }^{32-34}$ The immunoperoxidase technique was employed with the peroxidase substrate 3-amino-9-ethylcarbazole (AEC), which yielded a pink/red reaction product. Some sections were counterstained with Mayer's haematoxylin. Controls were applied to all immunostaining procedures as previously described. ${ }^{32-34}$

Sections employed in the autoradiographic and immunohistochemical studies were examined and compared by bright field and differential interference contrast microscopy. Semi-quantitative assessments of hybridisation or immunohistochemical labelling were made as previously described. ${ }^{27}$ Thus labelling at the level of the negative controls was designated 'background labelling', labelling equivalent to the most intense seen in positive controls was called 'intense labelling' and labelling inter-
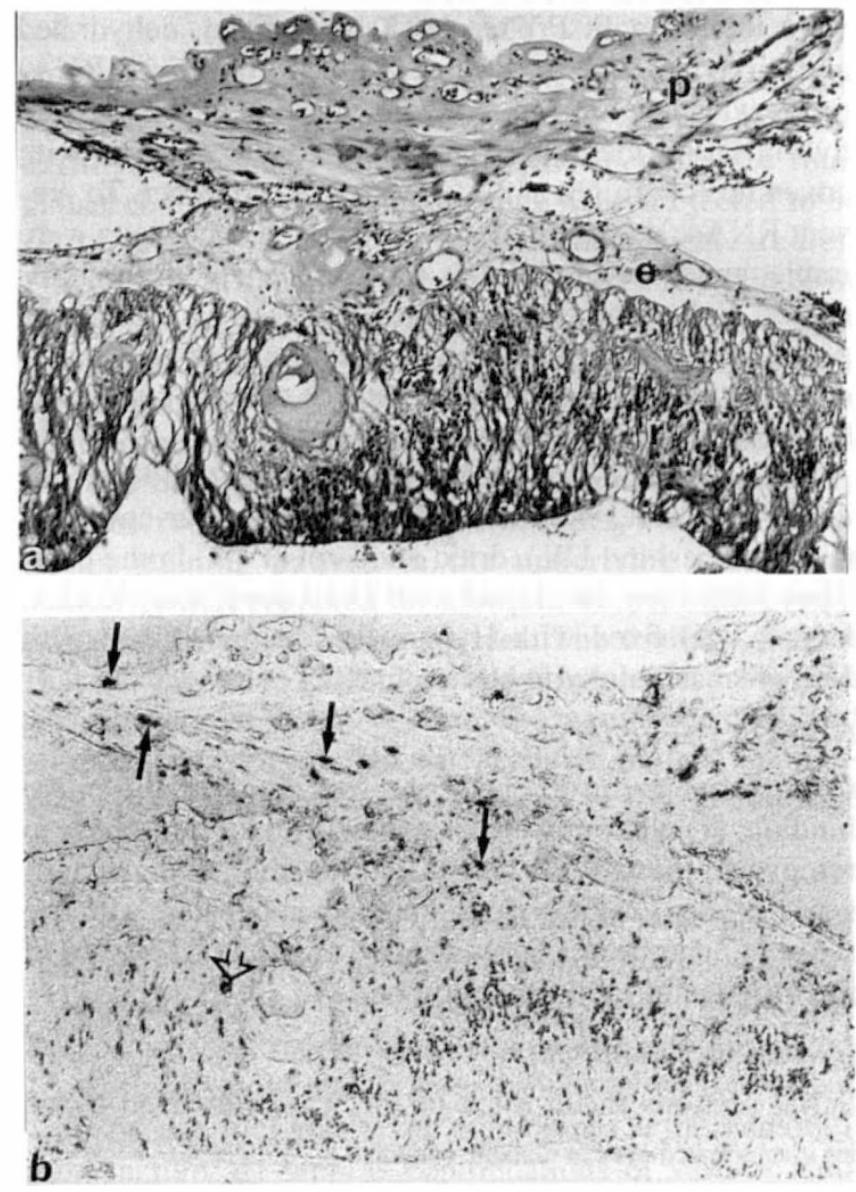

Fig. 1. Differential interference contrast micrographs of sections through retina. (a) Stained with haematoxylin and eosin to reveal the detached retina $(r)$ with overlying fibrovascular epiretinal membrane (e). The fibrovascular tissue extends onto/into the vitreous cortex ( $p$ ). (b) A sequential section labelled with the anti-sense probe for fibronectin and counterstained with haematoxylin. Many of the cells in the epiretinal and posterior hyaloid membranes label intensely for fibronectin mRNA (arrows), including spindle-shaped cells. A macrophage-like cell in the retina shows labelling for fibronectin $M R N A$ (open arrow'). $\times 125$. mediate between intense and background was termed 'moderate labelling'.

\section{RESULTS}

\section{Retina}

In three of the four globes, occasional isolated round cells exhibiting moderate or intense anti-sense probe binding were observed in the retina (Fig. 1). These cells often showed a macrophage-like morphology and frequently contained pigment. In addition, moderate labelling for fibronectin mRNA was seen in cells in the walls of some retinal vessels. The remaining retinal cells exhibited background levels of signal for fibronectin mRNA.

Moderate or intense fibronectin immunoreactivity was observed in the lumina and walls of retinal vessels. Foci of extravascular fibronectin also were seen around some vessels and occasionally patchy fibronectin staining was seen in the inner or outer retina (Fig. 2). The extravascular fibronectin staining pattern was similar to that of albumin
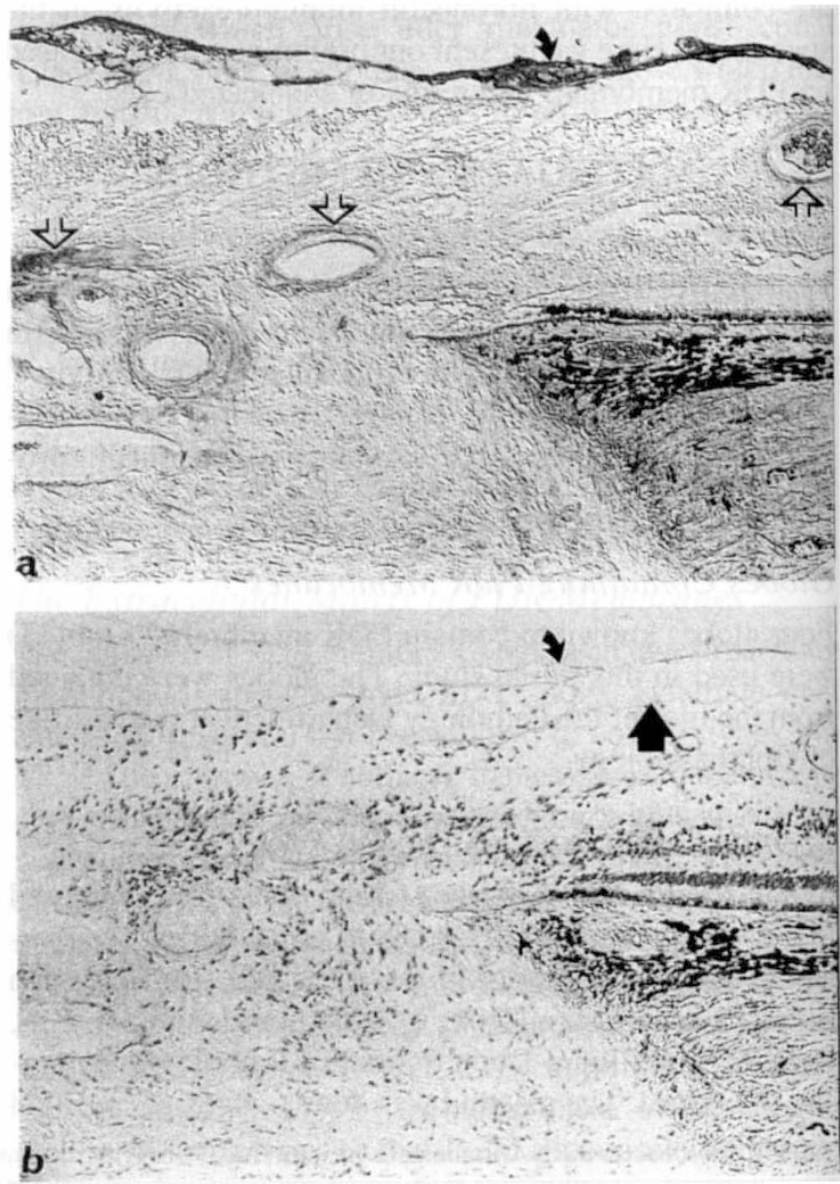

Fig. 2. Serial sections from parapapillary retina and adjacent optic nerve head. (a) Stained with the immunoperoxidase technique for fibronectin (no counterstain). An epipapillary and epiretinal membrane (curved arrow) exhibits intense fibronectin immunoreactivity. Extravascular fibronectin staining is also seen around retinal or optic nerve head vessels and in the neural tissue (open arrows). (b) Labelled with the anti-sense probe for fibronectin mRNA and counterstained with haematoxylin. No labelling is seen in the epiretinallepipapillary membrane (curved arrow'), retina (arrow' delineates retinal surface) or optic nerve head. $\times 125$. 
in retina following breakdown of the blood-retina bar$\operatorname{rier}^{35}$ and did not appear to be related to the distribution of the isolated fibronectin mRNA-containing cells.

\section{Intravitreal Membranes}

PDR membranes in two of the four globes contained cells which labelled with the anti-sense probe (Fig. 1; Table I); in one specimen $60 \%$ of the cells showed levels of labelling above background and a third of these cells exhibited intense labelling. The remaining fibronectin mRNA-containing membrane cells showed moderate probe binding (Table I). Patchy, moderate to intense fibronectin immunoreactivity was observed in all the PDR membranes, including those which did not contain cells that bound the anti-sense probe (Fig. 2).

The PDR membrane cells which contained fibronectin mRNA were isolated in the specimens, and aggregated cells were not observed in the membranes. It was not possible to trace individual cells through sequential autoradiographic and immunohistochemical sections with any degree of accuracy and, therefore, we could not determine the origins of the cells which labelled with the fibronectin. However, fibronectin mRNA was observed in both spindle-shaped fibroblast-like cells and rounded macrophage-like cells in the membranes (Fig. 1). Endothelial cells in some membrane vessels also showed moderate labelling with the anti-sense probe.

\section{DISCUSSION}

We were surprised to find intraretinal macrophage-like cells which contained fibronectin mRNA in the eyes since, in a previous study, ${ }^{27}$ we did not see comparable cells in detached retina in globes from non-diabetic patients. The reason for the difference between the two studies is obscure. However, intraretinal phagocytic cells may be seen in $\mathrm{PDR}^{36}$ and macrophages are known to produce fibronectin (which can act as an opsinising agent). ${ }^{37}$

Our results show that fibronectin immunostaining is present in PDR membranes devoid of cells containing detectable fibronectin mRNA. The lack of fibronectinproducing cells in some fibronectin-containing membranes could reflect deposition of insoluble cellular fibronectin by cells which have subsequently degenerated or migrated out of long-standing tissue. However, developing PDR membranes may incorporate fibronectin from the vitreous since the vitreous in PDR contains a soluble form of the glycoprotein. ${ }^{23}$ Vitreous fibronectin is presumed to be derived from the plasma following breakdown of the blood-retina barrier, ${ }^{22}$ and the pattern of intraretinal fibronectin immunoreactivity in our specimens concurs with this concept. ${ }^{35}$ Thus our findings support the idea that some of the fibronectin in the developing tissue originates from plasma-derived, vitreous fibronectin.

Conversely, cells in some well-established PDR membranes are replete with fibronectin message, indicating that fibronectin within PDR membranes partly originates from the membrane cells themselves. Indeed, recent immunohistochemical investigations demonstrate that
PDR membranes may contain insoluble cellular fibronectin. ${ }^{24-26}$ Consequently, it seems likely that the fibronectin in PDR membranes originates from both the membrane cells and plasma-derived fibronectin.

The agglomeration of both cellular and plasma fibronectin in PDR membranes is comparable to that seen in reparative tissues elsewhere in the body. ${ }^{37}$ For example, plasma and locally produced fibronectin collect in healing myocardial infarcts, ${ }^{38}$ and recently we have found evidence that the fibronectin in epiretinal and subretinal membranes of proliferative vitreoretinopathy is also derived from the plasma and membrane cells. ${ }^{27,39}$

Fibronectin-producing cells in periretinal membranes of proliferative vitreoretinopathy included retinal pigment epithelial, * glial, fibroblastic and macrophage-like cells. ${ }^{27,39}$ Fibroblast-like and macrophage-like cells with abundant fibronectin mRNA were present in PDR membranes and some of these cells may have been glial or, possibly, retinal pigment epithelial in origin. However, we were unable to distinguish the precise origins of the fibronectin-producing cells (other than vascular endothelia which sometimes exhibited moderate levels of fibronectin mRNA) in this preliminary study because of the absence of well-defined cell aggregates within the established PDR membranes. We hope to clarify further the origins of fibronectin-producing cells in our continuing investigations (employing PDR membrane biopsies obtained at vitrectomy).

The abundance of locally produced and plasma-derived fibronectin, together with previous observations of related ECM glycoproteins and cell surface receptors of the integrin family, ${ }^{40}$ in PDR membranes indicate that the ECM has an important role in PDR membrane progression. Moreover, the present evidence suggests that ECM-integrin interactions represent potential therapeutic targets in preventing PDR membrane formation.

This work was funded by the Wellcome Trust (grant no. 17095/ 1.4R) and the Joint Research Board (St. Bartholomew's Hospital). Mr. R. Howes provided photographic help. Dr Scott is Muir Hambro Fellow of the Royal College of Physicians.

Key words: Epiretinal membrane, Extracellular matrix, Fibronectin, In situ hybridisation, Immunohistochemistry, Proliferative diabetic retinopathy.

\section{REFERENCES}

1. Reeser FH, Aaberg TM. Vitreous humor. In: Records RE, editor. Physiology of the human eye and visual system. Hagerstown: Harper and Row, 1979:261-95.

2. McLeod D. Closed microsurgery for advanced diabetic eye disease. In: Kanski JJ, Morse PH, editors. Disorders of the vitreous, retina and choroid. London: Butterworth, 1983: 176-209.

3. McLeod D, James C. Viscodelamination at the vitreoretinal juncture in severe diabetic eye disease. $\mathrm{Br} \mathrm{J}$ Ophthalmol 1988;72:413-9.

4. Boulton ME, McLeod D, Garner A. Vasoproliferative retinopathies: clinical, morphogenic and modulatory aspects. Eye 1988;2(Suppl):124-39.

5. Barry PJ, Hiscott P, Grierson I, Marshall J, McLeod D. Reparative epiretinal fibrosis after diabetic vitrectomy. Trans Ophthalmol Soc UK 1985;104:285-96. 
6. Constable IJ, Tolentino FI, Donovan RH, Schepens CL. Clinico-pathologic correlation of vitreous membranes. In: Pruett RD, Regan DJ, editors. Retinal congress. New York: Appleton-Century-Crofts, 1974:254-7.

7. Smith RS, van Heuven WAJ, Streeten B. Vitreous membranes: a light and electron microscopic study. Arch Ophthalmol 1976;94:1556-60.

8. Clarkson JG, Green WR, Massof D. A histopathologic review of 168 cases of preretinal membrane. Am J Ophthalmol 1977;84:1-17.

9. Kampik A, Kenyon KR, Michels RG, Green WR, de la Cruz ZC. Epiretinal and vitreous membranes: comparative study of 56 cases. Arch Ophthalmol 1981;99:1445-54.

10. Hamilton CW, Chandler D, Klintworth GK, Machemer R. A transmission and scanning electron microscopic study of surgically excised preretinal membrane proliferations in diabetes mellitus. Am J Ophthalmol 1982;94:479-88.

11. Garner A. Ocular angiogenesis. Int Rev Exp Pathol 1986;28: 249-306.

12. Jerdan JA, Michels RG, Glaser BM. Diabetic preretinal membranes: an immunohistochemical study. Arch Ophthalmol 1986;104:286-90.

13. Ohira A, de Juan E. Characterisation of glial involvement in proliferative diabetic retinopathy. Ophthalmologica 1990; 201:187-95.

14. Grierson I, Rahi AHS. Structural basis of contraction in vitreal fibrous membranes. Br J Ophthalmol 1981;65:737-49.

15. Scheiffarth OF, Kampik A, Guenther H, v d Mark K. Proteins of the extracellular matrix in vitreoretinal membranes. Graefes Arch Clin Exp Ophthalmol 1988;226:357-61.

16. Pearlstein E, Gold LI, Garcio-Pardo A. Fibronectin: a review of its structure and biological activity. Mol Cell Biochem 1980;29:103-28.

17. Ruoslahti E, Pierschbacher MD. New perspectives in cell adhesion: RGD and integrins. Science 1987;238:491-7.

18. Engel J. Domains in proteins and proteoglycans of the extracellular matrix with functions in assembly and cellular activities. Int J Biol Macromol 1991;13:147-51.

19. Hynes RO. Integrins: a family of cell surface receptors. Cell 1987;48:549-54.

20. Ruoslahti E. Integrins. J Clin Invest 1991;87:1-5.

21. Hogg N. An integrin overview. Chem Immunol 1991;50: $1-12$.

22. Campochiaro PA, Jerdan JA, Glaser BM. Vitreous aspirates from patients with proliferative vitreoretinopathy stimulate retinal pigment epithelial cell migration. Arch Ophthalmol 1985;103:1403-5.

23. Weller M, Wiedemann P, Heimann K, Zilles K. The significance of fibronectin in vitreoretinal pathology. Graefes Arch Clin Exp Ophthalmol 1988;226:294-8.

24. Immonen I, Tervo K, Virtanen I, Laatikainen L, Tervo T. Immunohistochemical demonstration of cellular fibronectin and tenascin in human epiretinal membranes. Acta Ophthalmol (Copenh) 1991;69:466-71.
25. Grisante S, Wiedemann P, Heiman K. The origin of fibronectin in periretinal membranes of PVR and PDR. Invest Ophthalmol Vis Sci 1992;33(Suppl):858.

26. Hiscott P, Larkin G, Robey HL, Orr G, Grierson I. Thrombospondin as a component of the extracellular matrix of epiretinal membranes: comparisons with cellular fibronectin. Eye 1992;6:566-9.

27. Hiscott P, Waller HA, Butler MG, Grierson I, Scott D. Local production of fibronectin by ectopic human retinal cells. J Cell Tissue Res 1992;267:185-92.

28. Waller HA, Butler MG, McClean JGB, Dowd GSE, Scott DL. The localisation of fibronectin mRNA in the rheumatoid synovium by in situ hybridisation. Br J Rheumatol 1991;29(Suppl):36.

29. Kornblihtt AR, Vibe-Pedersen K, Baralle FE. Isolation and characterisation of cDNA clones for human and bovine fibronectins. Proc Natl Acad Sci USA 1983;80:3218-22.

30. Kornblihtt AR, Vibe-Pedersen K, Baralle FE. Human fibronectin: molecular cloning evidence for two mRNA species differing by an internal segment coding for a structural domain. EMBO J 1984;3:221-6.

31. Sambrook J, Fritsch EF, Maniatis T. Molecular cloning: a laboratory manual, 2nd ed. New York: Cold Spring Harbor Laboratory Press, 1989.

32. Hiscott PS, Grierson I, Trombetta CJ, Rahi AHS, Marshall J, McLeod D. Retinal and epiretinal glia: an immunohistochemical study. Br J Ophthalmol 1984:68:698-707.

33. Hiscott PS, Grierson I, McLeod D. Retinal pigment epithelial cells in epiretinal membranes: an immunohistochemical study. Br J Ophthalmol 1984;68:708-15.

34. Hiscott PS, Grierson I, McLeod D. Natural history of fibrocellular epiretinal membranes: a quantitative, autoradiographic and immunohistochemical study. Br J Ophthalmol 1985;69:810-23.

35. Vinores SA, Gadegbeku C, Campochiaro PA, Green WR. Immunohistochemical localisation of blood-retinal barrier breakdown in human diabetes. Am J Pathol 1989;134: 231-5.

36. Green WR. Retina. In: Spencer WH, ed. Ophthalmic pathology: an atlas and textbook, 3rd ed. Philadelphia: WB Saunders, 1985:589-1291.

37. d'Ardenne AJ, McGee JO'D. Fibronectin in disease. J Pathol 1984;142:235-51.

38. Casscells W, Kimura H, Sanchez JA, Yu Z, Ferrans VJ. Immunohistochemical study of fibronectin in experimental myocardial infarction. Am J Pathol 1990;137:801-10.

39. Hiscott P, Waller HA, Butler MG, Grierson I, Scott DL, Gregor Z, Morino I. Fibronectin synthesis in subretinal membranes of proliferative vitreoretinopathy. Br J Ophthalmol 1992;76:486-90.

40. Weller M, Wiedemann P, Bresgen M, Heimann K. Vitronectin and proliferative intraocular disorders. II. Expression of cell surface receptors for fibronectin and vitronectin in periretinal membranes. Int Ophthalmol 1991;15: 103-8. 